\title{
Studies on Genetic Diverity in Rice (Oryza sativa L.)
}

\author{
C.A. Sowmiya* and M. Venkatesan \\ Department of Genetics \& Plant Breeding, Faculty of Agriculture, Annamalai University, \\ Annamalai Nagar - 608 002, Tamil Nadu, India \\ *Corresponding author
}

\begin{tabular}{|c|c|}
\hline \multicolumn{2}{|r|}{ A B S T R A C T } \\
\hline & \multirow{5}{*}{$\begin{array}{l}\text { The present investigation was conducted at Plant Breeding Farm, Department of Genetics } \\
\text { and Plant Breeding, Faculty of Agriculture, Annamalai University during } 2015-2017 \text {. } \\
\text { The experiment was carried out to explore the extent of divergence in } 48 \text { rice genotypes } \\
\text { for nine characters. In } \mathrm{D}^{2} \text { analysis, the } 48 \text { genotypes were grouped into nine clusters. The } \\
\text { clustering pattern indicated that there was no parallelism between genetic diversity and } \\
\text { geographical origin as the genotypes from different origins were included in same clusters } \\
\text { and vice versa. The maximum intra cluster distance was registered in cluster VIII (35.87). } \\
\text { The maximum inter cluster distance was found between Cluster VI and Cluster VIII } \\
\text { (54.23) followed by Cluster VIII and IX ( } 51.01 \text { ), cluster V and VIII (50.26) and cluster III } \\
\text { and VIII ( } 45.60 \text { ). Genetically distant parents from those clusters could be able to produce } \\
\text { higher heterosis in progenies on hybridization. Grain yield per plant and thousand grain } \\
\text { weight were the major contributors towards the total genetic divergence among the } \\
\text { genotypes studied. Selection could be made based on grain yield per plant and thousand } \\
\text { grain weight for the progenies identified. }\end{array}$} \\
\hline & \\
\hline $\begin{array}{l}\text { Divergence, } \\
\mathrm{D}^{2} \text { analysis, Intra } \\
\text { cluster, Inter } \\
\text { cluster and } \\
\text { heterosis. }\end{array}$ & \\
\hline Article Info & \\
\hline & \\
\hline
\end{tabular}

\section{Introduction}

Rice (Oryza sativa L.), native of India or Africa, is commonly known as arisi, nellu or chawal in India. The cultivated species are diploid with $2 n=24$ whereas the wild species are tetraploid with $2 n=4 x=48$. It is a selfpollinated crop with mechanism of cleistogamy. It is one of the very few crop species endowed with rich genetic diversity which account over one lakh landraces and improved cultivars (Samal et al., 2014). In India, the overall rice production by the year 2015 - 2016 was 104.4 million tons whereas by the year $2014-2015$ the production was estimated as 105.5 million tons and productivity as $2391 \mathrm{~kg} \mathrm{ha}^{-1}$ under 44.1 million ha (Indiastat, 2017).
Genetic diversity is a powerful tool to determine the genetic discrimination among the genotypes which can be used to select appropriate parental genotypes for hybridization to develop high yielding potential variety (Bhatt, 1970). Diversity not only results in inducing genetic variation but also provides new recombination of genes in gene pool.

Using advanced biometric techniques such as multivariate analysis based on Mahalanobis $\mathrm{D}^{2}$ statistic (Mahalanobis, 1936), it has now become possible to quantify the degree of genetic divergence amongst biological populations and assessing the relative 
contribution of various desirable attributes of breeding and agronomic value to the total divergence. The investigation was about estimation of magnitude of genetic divergence of 48 rice genotypes and to identify diverse genotypes for the future study.

\section{Materials and Methods}

Seeds of forty eight genotypes were sown in raised nursery beds during February, 2016. In each genotype, one seedling per hill was transplanted in the main field after 25 days with spacing of $20 \mathrm{~cm} \mathrm{X} 20 \mathrm{~cm}$. The experiments were conducted at Experimental Farm of Plant Breeding ( $11^{0} 24^{\prime}$ N latitude and 79 44 ' E longitude, + 5.79 MSL), Annamalai University, Tamil Nadu, India. The experiment was carried out in Randomized Block Design with three replications. As recommended, agronomic and plant protection measures were followed during the crop period.

A uniform population of 12 plants in a row was maintained. The experiment was conducted to explore the extent of divergence in 48 rice genotypes for nine characters viz., days to first flower, plant height, number of tillers per plant, number of panicles per plant, number of grains per panicle, panicle length, thousand grain weight, grain L/B ratio and grain yield per plant. The analysis of genetic divergence was done using Mahalonobis (1936) $\mathrm{D}^{2}$ statistics. The genotypes were grouped into different clusters, inter and intra cluster distances and mean performances for characters were also computed.

\section{Results and Discussion}

Analysis of variance for different characters is presented in table 1. Using advanced biometric techniques such as multivariate analysis based on Mahalanobis $\mathrm{D}^{2}$ statistic (Mahalanobis, 1936), it has now become possible to quantify the degree of genetic divergence amongst populations and assessing the relative contribution of various desirable attributes of breeding and agronomic value to the total divergence by the clustering pattern. The grouping of genotypes into so many clusters had suggested the presence of high degree of diversity in the materials evaluated. Earlier workers had also reported presence of substantial genetic diversity in rice (Kumar et al., 2014; Ahmed et al., 2014; Sandhya et al., 2015).

Among the nine clusters, cluster I accommodated maximum of 19 genotypes followed by cluster IX of 10 genotypes and cluster VIII of 7 genotypes. The remaining clusters i.e. II, III, IV, V, VI and VII were accommodated with two genotypes. The genotypes included in cluster I originated from different origins indicating that there was no parallelism between clustering pattern and geographic distribution of genotypes (Nayak et al., 2004). Distribution of rice genotypes in different clusters was furnished in table 2.

Intra (bold) and inter cluster (unbold) $\mathrm{D}^{2}$ values and $\mathrm{D}$ (unbold) values in rice are tabulated in tables 3 and 4 and in figure 1 . The highest intra cluster distance was registered in cluster VIII (35.87) followed by cluster IX (32.82) and cluster I (28.70). Thus the genotypes from those clusters had high degree of divergence that would produce more desirable segregants for achieving greater genetic advance.

The least intra cluster distance was revealed in cluster II (4.63) followed by cluster III (7.75) and cluster IV (9.22) indicating homogenous nature of the genotypes with less deviation between the genotypes. Parallel findings were found by Nirosha et al., (2016), Mamta Kumari et al., (2016) and Hossain et al., (2015). 
Table.1 Analysis of variance for nine characters in rice genotypes

\begin{tabular}{|c|c|c|c|c|c|c|c|c|c|c|c|}
\hline Sl.No. & Source & df & $\begin{array}{c}\text { Days to } \\
\text { first } \\
\text { flower } \\
\text { (days) }\end{array}$ & $\begin{array}{c}\text { Plant } \\
\text { height } \\
\text { (cm) }\end{array}$ & $\begin{array}{c}\text { No. of } \\
\text { tillers } \\
\text { per } \\
\text { plant }\end{array}$ & $\begin{array}{c}\text { No. of } \\
\text { panicles } \\
\text { per } \\
\text { plant }\end{array}$ & $\begin{array}{c}\text { No. of } \\
\text { grains per } \\
\text { panicle }\end{array}$ & $\begin{array}{c}\text { Panicle } \\
\text { length } \\
\text { (cm) }\end{array}$ & $\begin{array}{c}\text { Thousand } \\
\text { grain } \\
\text { weight }\end{array}$ & $\begin{array}{c}\text { Grain } \\
\text { L/B } \\
\text { ratio }\end{array}$ & $\begin{array}{c}\text { Grain } \\
\text { yield per } \\
\text { plant (g) }\end{array}$ \\
\hline & & & \multicolumn{9}{|c|}{ MSS } \\
\hline 1. & Replication & 2 & 75.55 & 4.98 & 4.32 & 3.31 & 297.28 & 1.77 & 0.36 & 0.02 & 0.46 \\
\hline 2. & Genotype & 47 & $448.13 * *$ & $788.95 * *$ & $292.72 * *$ & $146.37 * *$ & $17721.09 * *$ & $24.31 * *$ & $29.30 * *$ & $0.90 * *$ & $450.35 * *$ \\
\hline 3. & Error & 94 & 19.73 & 7.23 & 2.85 & 3.01 & 938.31 & 2.26 & 0.10 & 0.01 & 0.37 \\
\hline
\end{tabular}

** Significant at $1 \%$ level

Table.2 Distribution of rice genotypes in different clusters based on $\mathrm{D}^{2}$ analysis

\begin{tabular}{|c|c|l||}
\hline Cluster No & $\begin{array}{c}\text { Number of } \\
\text { genotypes }\end{array}$ & \multicolumn{1}{c|}{ List of the genotypes } \\
\hline I & 19 & $\begin{array}{l}\text { ADT 47, ADT 41, ADT 37, ADT 36, ADT 45, ADT 48, ADT 43, ADT 42, ASD 16, } \\
\text { ASD 18, IR 66, IR 64, IR 72, IR 50, TPS 5, CO 51, CO 47, Jaya Mathi, MTU 1156 }\end{array}$ \\
\hline II & 2 & IET 14348, MTU 7029 \\
\hline III & 2 & STBN 18, Bhavani \\
\hline IV & 2 & MDU 5, PY 3 \\
\hline V & 2 & Geetanjali, Sama Mashuri \\
\hline VI & 2 & AVT 1320, AVT 1321 \\
\hline VII & 2 & MTU 1121, MTU 1010 \\
\hline VIII & 7 & TRY 2, TKM 9, PMK 3, AVT 1303, Dhanya Lakshmi, IR 20, Super Amman \\
\hline IX & 10 & $\begin{array}{l}\text { Angur Selam, ASD 1, PLA 1100, K. Sona, AVT 1302, Kullakar, Pooughar, IR 36, NLR } \\
\text { 34449, Akshaya }\end{array}$ \\
\hline
\end{tabular}


Table.3 Intra (bold) and inter cluster (unbold) $\mathrm{D}^{2}$ values of various clusters in rice

\begin{tabular}{|c|c|c|c|c|c|c|c|c|c|}
\hline Cluster no. & I & II & III & IV & $\mathbf{V}$ & VI & VII & VIII & IX \\
\hline I & 823.66 & 1296.21 & 1345.02 & 667.38 & 1760.43 & 2033.09 & 1166.63 & 1138.41 & 1998.20 \\
\hline II & & 21.40 & 49.83 & 329.83 & 155.52 & 426.51 & 71.33 & 1988.60 & 615.30 \\
\hline III & & & 59.98 & 407.21 & 175.14 & 334.87 & 141.25 & 2079.67 & 662.27 \\
\hline IV & & & & 85.08 & 736.41 & 918.62 & 267.05 & 1194.36 & 997.33 \\
\hline $\mathbf{V}$ & & & & & 122.00 & 440.03 & 275.38 & 2526.30 & 638.02 \\
\hline VI & & & & & & 144.65 & 564.37 & 2940.36 & 846.72 \\
\hline VII & & & & & & & 156.11 & 1791.71 & 699.23 \\
\hline VIII & & & & & & & & 1286.55 & 2602.09 \\
\hline IX & & & & & & & & & 1076.80 \\
\hline
\end{tabular}

Table.4 Average intra (bold) and inter cluster D (unbold) values in rice

\begin{tabular}{|c|c|c|c|c|c|c|c|c|c|}
\hline Cluster no. & $\overline{\bar{I}}$ & II & III & IV & $\overline{\mathrm{V}}$ & $\overline{\text { VI }}$ & VII & VIII & IX \\
\hline I & 28.70 & 36.00 & 36.67 & 25.83 & 41.96 & 45.09 & 34.16 & 33.74 & 44.70 \\
\hline II & & 4.63 & 7.06 & 18.16 & 12.47 & 20.65 & 8.45 & 44.59 & 24.81 \\
\hline III & & & 7.75 & 20.18 & 13.23 & 18.30 & 11.89 & 45.60 & 25.74 \\
\hline IV & & & & 9.22 & 27.14 & 30.31 & 16.34 & 34.56 & 31.58 \\
\hline $\mathbf{V}$ & & & & & 11.05 & 20.98 & 16.59 & 50.26 & 25.26 \\
\hline VI & & & & & & 12.03 & 23.76 & 54.23 & 29.10 \\
\hline VII & & & & & & & 12.49 & 42.33 & 26.44 \\
\hline VIII & & & & & & & & 35.87 & 51.01 \\
\hline IX & & & & & & & & & 32.82 \\
\hline
\end{tabular}


Table.5 Cluster means of rice genotypes for different traits

\begin{tabular}{|c|c|c|c|c|c|c|c|c|c|}
\hline Clusters & $\begin{array}{c}\text { Days to } \\
\text { first } \\
\text { flower }\end{array}$ & $\begin{array}{l}\text { Plant } \\
\text { height } \\
(\mathbf{c m})\end{array}$ & $\begin{array}{l}\text { Number } \\
\text { of tillers } \\
\text { per plant }\end{array}$ & $\begin{array}{c}\text { Number of } \\
\text { panicles } \\
\text { per plant }\end{array}$ & $\begin{array}{c}\text { Number of } \\
\text { grains per } \\
\text { panicle }\end{array}$ & $\begin{array}{c}\text { Panicle } \\
\text { length } \\
\text { (cm) }\end{array}$ & $\begin{array}{l}\text { Thousand } \\
\text { grain } \\
\text { weight (g) }\end{array}$ & $\begin{array}{c}\text { Grain } \\
\text { L/B } \\
\text { ratio }\end{array}$ & $\begin{array}{c}\text { Grain yield } \\
\text { per plant }(\mathrm{g})\end{array}$ \\
\hline Cluster I & 79.39 & 90.68 & 21.47 & 15.20 & 156.67 & 23.13 & 18.28 & 4.19 & 28.38 \\
\hline Cluster II & 94.84 & 100.46 & 25.30 & 15.31 & 220.17 & 23.12 & 18.61 & 4.02 & 11.19 \\
\hline Cluster III & 96.04 & 98.91 & 20.96 & 12.17 & 287.66 & 23.20 & 18.60 & 4.37 & 10.67 \\
\hline Cluster IV & 79.85 & 85.96 & 32.01 & 22.91 & 207.72 & 23.50 & 19.28 & 3.97 & 20.45 \\
\hline Cluster V & 90.03 & 114.43 & 21.33 & 11.52 & 209.30 & 27.93 & 16.54 & 4.18 & 7.91 \\
\hline Cluster VI & 73.01 & 96.72 & 26.14 & 14.57 & 182.77 & 25.62 & 18.12 & 5.54 & 6.51 \\
\hline Cluster VII & 93.61 & 100.45 & 26.59 & 18.36 & 137.23 & 24.88 & 19.30 & 4.00 & 13.07 \\
\hline Cluster VIII & 88.36 & 113.50 & 28.56 & 20.43 & 212.70 & 24.63 & 19.24 & 4.24 & 32.86 \\
\hline Cluster IX & 93.53 & 112.77 & 35.46 & 20.05 & 211.99 & 23.19 & 16.66 & 4.41 & 10.10 \\
\hline
\end{tabular}

Table.6 Relative contribution of different characters to genetic divergence

\begin{tabular}{|c|l|c||}
\hline S. No. & \multicolumn{1}{|c|}{ Characters } & Per cent contribution \\
\hline 1. & Days to first flower & 0.80 \\
\hline 2. & Plant height & 0.80 \\
\hline 3. & Number of tillers per plant & 4.87 \\
\hline 4. & Number of panicles per plant & 0.35 \\
\hline 5. & Number of grains per panicle & 0.35 \\
\hline 6. & Panicle length & 11.26 \\
\hline 7. & Thousand grain weight & 3.99 \\
\hline 8. & Grain L/B ratio & 76.78 \\
\hline 9. & Grain yield per plant & \\
\hline
\end{tabular}


Fig.1 Clustering pattern based on D values (not to scale) in rice genotypes

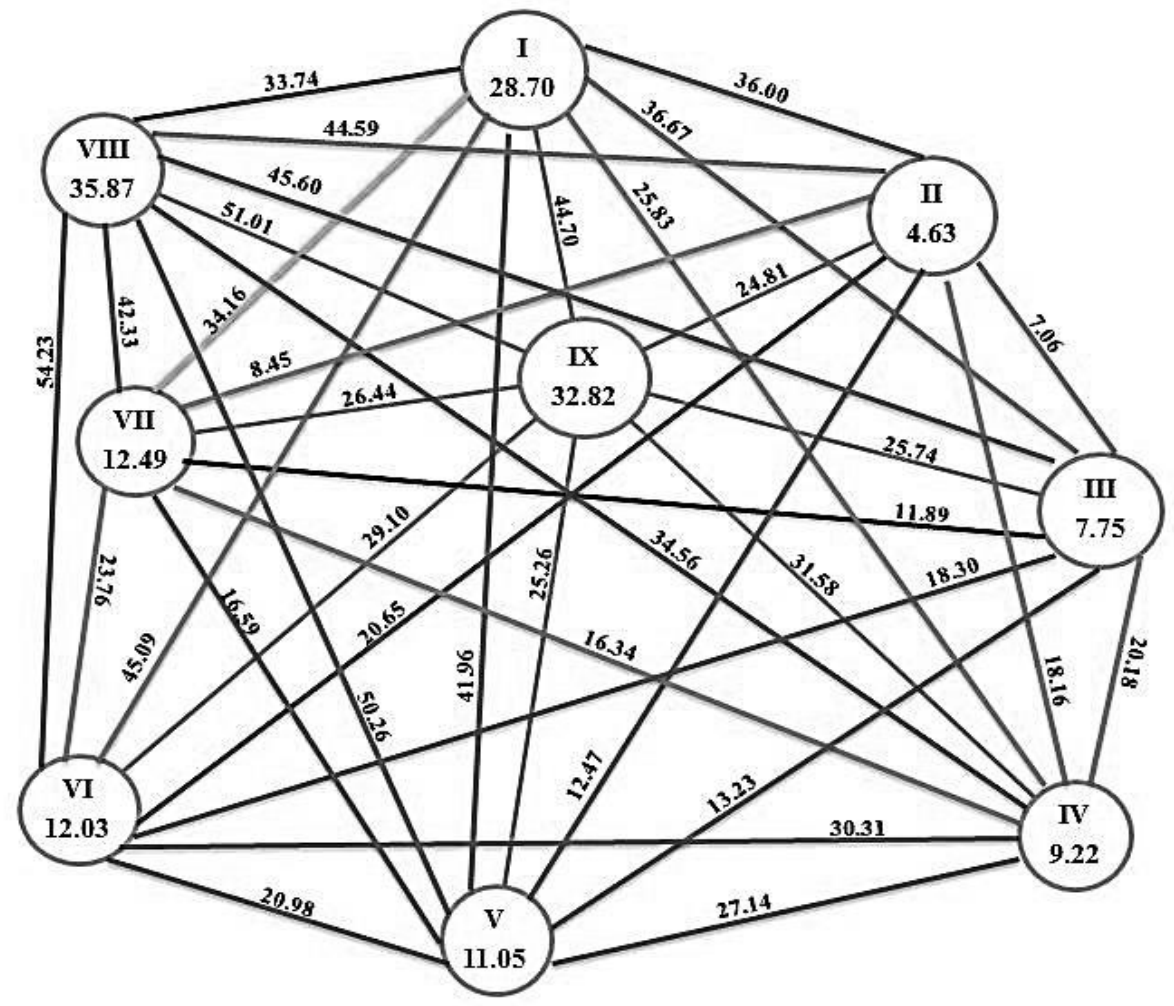

Highest inter cluster distance (54.23) was found between cluster VI and VIII followed by cluster VIII and IX (51.01), cluster V and VIII (50.26), cluster III and VIII (45.60) and cluster I and VI (45.09) indicating the wider genetic diversity among the genotypes between these clusters. This indicated that the genotypes in these clusters had broad spectrum of genetic diversity and could very well be used in hybridization programme. Similar results were reported by Yadav et al., (2011) and Sandhya et al., (2015).

The minimum inter cluster distance was found between cluster II and III (7.06). The inter cluster distances were greater than intra cluster indicating wide genetic diversity among genotypes. Similar results were reported by Banumathy et al., (2010), Toshimenla et al., (2016), Vijay Kumar (2015), Chamundeswari (2016) and Nirosha et al., (2016).
The overall clustering pattern indicated that genotypes developed in same geographical region were distributed in different clusters. Shanmugam and Rangasamy (1982) reported that grouping of material of same geographical origin into different clusters was an indication of the broad genetic base of genotypes belonging to that origin. Similar results of non-association of geographical region with the genetic diversity were reported by Mohan et al., (2015), Vijay Kumar (2015), Toshimenla et al., (2016), Chandramohan et al., (2016) and Thippeswamy et al., (2016).

Cluster mean analysis revealed a wide range of variation for all the traits under study (Table 5). Cluster VI chronicled earliness in flowering and might be utilized as a suitable source for incorporation of earliness in other genotypes. Cluster IV reported minimum cluster mean for plant height. Hence 
genotypes from the cluster could be made use in development of dwarf and semi - dwarf lines or the trait could be transferred into other desirable genotypes. Cluster VIII had the maximum cluster mean value for grain yield per plant. Hence the genotypes could be utilized in yield improvement breeding programmes.

The relative contribution of each characters towards $\mathrm{D}^{2}$ depends upon the inter cluster distances in all combinations (Table 6). The selection and choice of parents mainly depends upon contribution of characters towards divergence. In the present investigation, the highest contribution in manifestation of genetic divergence was exhibited by grain yield per plant (gm) (76.78\%) followed by thousand grain weight (gm) (11.26\%). Next to the above characters number of panicles per plant $(4.87 \%)$ and grain L/B ratio (3.99\%) had moderately contributed towards the genetic divergence. Hence grain yield per plant and thousand grain weight should be given importance during choice of parents for hybridization and selection in the segregating populations.

\section{References}

Ahmed, A., S.G. Shaon, M.S. Islam, P.S. Saha and M.M. Islam. 2014. Genetic divergence analysis in HRDC rice (Oryza sativa L.) hybrids in Bangladesh. Bangladesh J. Pl. Breed. Genet., 27(2): 25-32.

Banumathy, S., R. Manimaran, A. Sheeba and N. Manivannan. 2010. Genetic divergence analysis of rice germplasm lines for yield attributing traits. Electronic J. of Plant Breed., 4(2): 102105.

Bhatt, G.M., 1970. Multivariate analysis approach to selection of parents of hybridization aiming at yield improvement in self - pollinated crops.
Australian J. of Agricultural Research, 21: 1-7.

Chamundeswari, N., 2016. Studies on nature of genetic divergence in rice (Oryza sativa L.). Intl. J. of Science, Environment, 5(6): 4018-4023.

Chandramohan, Y., B. Srinivas, S. Thippeswamy and D. Padmaja. 2016. Diversity and variability analysis for yield parameters in rice (Oryza sativa L.) genotypes. Indian J. Agric. Res., 50(6): 609-613.

Hossain, S., M. Salim, M.S. Akter, S. Afroz and M.S. Noman. 2015. Genetic diversity of drought tolerant upland rice (Oryza sativa L.) genotypes. A Scientific J. Krishi Foundation, 13(2): 133-139.

http://www.indiastat.com

Kumar, B., Gupta, B.B. and Singh B. 2014. Genetic diversity for morphological and quality traits in rice (Oryza sativa L.). The Bioscan, 9(4): 1759-1762.

Mahalanobis, P.C., 1936. On the generalized distance in statistics. Poc. Nat. Inst. Sci. (India), 2: 49-55.

Mamta Kumari, G., Suresh Babu and Nithin B. Patel. 2016. Genetic diversity analysis of rice (Oryza sativa L.) germplasm under aerobic condition. Bangladesh J. Bot., 45(3): 727-732.

Mohan, Y.C., S. Thippeswamy, K. Bhoomeshwar, B. Madhavilatha and Jameema Samreen. 2015. Diversity analysis for yield and gall midge resistance in rice (Oryza sativa L.) in Northern Telangana zone, India. SABRAO J. of Breed. and Genet., 47(2): 160-171.

Nayak, A.R., D. Chaudhary and J.N. Reddy. 2004. Genetic divergence in scented rice. Oryza, 41:79-82.

Nirosha, R., S. Thippeswamy, V. Ravindrababu, V. Ram Reddy and B. Spandana. 2016. Genetic diversity analysis of zinc, iron, grain protein 
content and yield components in rice. Electronic J. Pl. Breed., 7(2): 371-377.

Samal, K.C., Meti, N., Bastia, D.N., Rout, G.R. 2014. Genetic diversity analysis of traditional aromatic rice using molecular markers. BMR, 1(2): 1-14.

Sandhya, Mukul, Kumari, S. and Babu. G.S. 2015. Estimation of genetic divergence among elite genotypes of rice (Oryza sativa L.). The Ecoscan., 9(1\&2): 409411.

Shanmugam A.S., and Rangasamy S.R.S. (1982). Genetic diversity for quantitative characters in greengram (Vigna radiate L.). The Madras Agric. J., 69:631-636.

Thippeswamy, S., Y. Chandramohan, B. Srinivas and D. Padmaja. 2016. Selection of diverse parental lines for heterotic hybrid development in rice (Oryza sativa L.). SABRAO J. of Breed, and Genet., 48(3): 285-294.

Toshimenla, Jogendra Singh and Sapu Changkija. 2016. Genetic divergence studies on upland rice grown in Nagaland, India. Indian J. Agric. Res., 50(6): 555-560.

Vijay Kumar, 2015. Genetic diversity and character association studies for some economic traits in rice (Oryza sativa L.). An Intl. Quarterly J. of Life Sci., 10(2): 899-904.

Yadav, S.K., P. Pandey, B. Kumar and B.G. Suresh. 2011. Genetic Architecture, Inter-relationship and selection criteria for yield improvement in rice (Oryza sativa L.). Pakistan J. of Biological Sci., 14(9): 540-545.

\section{How to cite this article:}

Sowmiya C. A. and Venkatesan M. 2017. Studies on Genetic Diverity in Rice (Oryza Sativa L.). Int.J.Curr.Microbiol.App.Sci. 6(9): 1749-1756. doi: https://doi.org/10.20546/ijcmas.2017.609.216 